\title{
USING HISTORIC SITES IN DETERMINING PLANT-SOIL INTERACTIONS UNDER LONG TERM CONTAMINATED SOILS
}

\author{
E .M.ABD EL LATEEF ${ }^{1}$, J.E. HALL ${ }^{2}$, A.A. YASSEN ${ }^{3}$, M.S. ABD EL-SALAM ${ }^{1}$, A.K.M. SALEM
}

${ }^{1}$ Field Crop Research Department, Agricultural Division, National Research Centre, Cairo, Egypt., ${ }^{2}$ Indpendant Consultant, London, United Kingdom., ${ }^{3}$ Plant Nutrition Department.Email: ezzlatnrc@hotmail.com

Received: 14 July 2021, Revised and Accepted: 20 August 2021

\section{ABSTRACT}

The relationships between heavy metals in soils and crop tissues are critical in understanding the potential risk to crop yields from $\mathrm{Zn}$, $\mathrm{Cu}$ and $\mathrm{Ni}$ (the principal phytotoxic elements of concern in sludge), and the possible effects on dietary Cd (the critical zootoxic element that is labile in sludgetreated soil and readily absorbed by plants. These relationships cannot be derived from the agronomic trials because the quantities of heavy metals applied to the soil in sludge are small. These are field sites have been treated with sludge for many years in operational practice and where the oncentrations of heavy metals have been significantly raised above background values, representing potentially a worse-case of soil contamination. The purpose of the study was to provide a surrogate for long-term sludge-treated agricultural soil by examining the effects on crops of heavy metals in soil irrigated with raw sewage effluent for periods of more than 80 years and containing significantly elevated concentrations of heavy metals. Methodology: Two surveys of the Gabal El Asfar Old Farm were undertaken to assess the long-term effects of heavy metals in sludge-treated soil on crop quality. In the first survey, the relationships between total and DTPA extractable heavy metals in soil and concentrations in citrus fruit were examined. Concentrations of heavy metals in leaves of citrus were measured in the second survey and related to total and DTPA extractable metals in soil.

The heavy metal contents of citrus leaves and fruit (orange - eleven sampling sites; mandarin - four sampling sites), and total and DTPA extractable concentrations in soils were measured in samples collected from different areas of the Farm during two site surveys. Total and DTPA concentrations of heavy metals in the surveyed soils showed significant enrichment by long-term irrigation with sewage effluent. For example, the maximum total concentrations of $\mathrm{Zn}$ and $\mathrm{Cu}$ were 530 and $366 \mathrm{mg} \mathrm{kg}-1$, respectively, representing a potential risk to crop yields The maximum Cd concentration detected was $9 \mathrm{mg} \mathrm{kg-1}$ and may be a potential risk to the human food chain from uptake into staple crops grown at the farm. DTPA extractable metals were significantly $(\mathrm{P}<0.001)$ correlated with the total contents of $\mathrm{Zn}\left(\mathrm{r}=0.91^{* * *}\right), \mathrm{Cu}\left(\mathrm{r}=0.83^{* * *}\right), \mathrm{Ni}\left(\mathrm{r}=0.63^{* * *}\right)$ and $\mathrm{Pb}\left(\mathrm{r}=0.85^{* * *}\right)$ in soil when data from both surveys were pooled for statistical evaluation. There was also evidence of a weak relationship between DTPA extractable Cd and the total soil Cadmium is the only element of concern in terms of the risk to human health from uptake into food crops grown on sludge-treated soil. The total $\mathrm{Cd}$ concentration in soil was raised to a value 3 times the maximum EU limit for this element in sludge-treated agricultural soil. Despite the marked increase in soil Cd content, there was no detectable transfer into citrus leaves or fruit (Figure 1). The absence of Cd uptake into citrus fruit is to be expected because fruits are amongst the least sensitive plant parts to Cd accumulation. These data emphasise the minimal risk to the human diet from $\mathrm{Cd}$ in fruit crops grown on sludge-treated soil. . In all cases, leaf tissue concentrations were low and in some cases Cu status was below the deficiency threshold. The Cd content in leaves was small and generally $<0.02 \mathrm{mg} \mathrm{kg}-1 \mathrm{DM}$.

Keywords: DTPA extraction, citrus, Cu, Cd, leaf concentration, soil concentration, toxicity, $\mathrm{Zn}$

(C) 2021 The Authors. Published by Innovare Academic Sciences Pvt Ltd. This is an open access article under the CC BY license (http://creativecommons.org /licenses/by/4.0/) DOI: http://dx.doi.org/10.22159/ijags.2021v9i5.41763. Journal homepage: https://innovareacademics.in/journals/index.php/ijags

\section{INTRODUCTION}

The Gabal El Asfar Old Farm is a government-owned fruit plantation situated on the north-eastern edge of Cairo on land that was originally desert. The farm has been irrigated with sewage for more than 80 years and there are environmental and health concerns about soil, water and crop contamination at the site and also about potentially toxic heavy metals. The extent of soil contamination at the site provides a model of the potential long-term effects of heavy metals on crops for sewage sludge-treated soils in Egypt. This adopts an approach followed by European scientists in assessing potential long-term impacts of recycling sewage sludge on agricultural land using sites with long histories of sludge application and referred to as so-called 'historic sites'. These are field sites which have been treated with sludge for many years in operational practice and where the concentrations of heavy metals have been significantly raised above background values, representing potentially a worsecase of soil contamination. Investigations using historic site soils provide a valuable adjunct to the classically designed and controlled field trials, for assessing the environmental effects of sewage sludge. Their value is due to the long period of time required for repeated sludge application to accumulate heavy metals in soil. If it can be demonstrated that there are minimal long-term risks to the environment under these worse-case conditions, this provides additional assurance and security about the long-term safety and sustainability of controlled recycling sewage sludge on agricultural land.

Several investigators studied the effect of long term irrigation of sewage in Gabal El Asfar farm ,[1,2,3,4,5].They found that found that the longer the period of irrigation with sewage effluent the higher the level of PTEs accumulation in soil

In India , Rattan et al reported that Sewage irrigation for 20 years resulted into significant build-up of DTPA-extractable Zn (208\%), Cu $(170 \%), \mathrm{Fe}(170 \%), \mathrm{Ni}(63 \%)$ and $\mathrm{Pb}(29 \%)$ in sewage-irrigated soils over adjacent tubewell water-irrigated soils, whereas Mn was depleted by $31 \%$. Soils receiving sewage irrigation for 10 years exhibited significant increase in $\mathrm{Zn}, \mathrm{Fe}, \mathrm{Ni}$ and $\mathrm{Pb}$, while only $\mathrm{Fe}$ in soils was positively affected by sewage irrigation for 5 years. Among these metals, only $\mathrm{Zn}$ in some samples exceeded the phytotoxicity limit. 


\section{Materials \&Methods}

Two surveys of the Gabal El Asfar Old Farm were undertaken as part of Cairo Sludge Disposal Study to assess the long-term effects of heavy metals in sludge-treated soil on crop quality. In the first survey, the relationships between total and DTPA extractable heavy metals in soil and concentrations in citrus fruit were examined. Concentrations of heavy metals in leaves of citrus were measured in the second survey and related to total and DTPA extractable metals in soil. The results of both surveys are summarized here and an integrated interpretation of the potential long-terms implications of heavy metals in sewage sludge recycled on agricultural land in Egypt.

Since the site is only irrigated with partially treated effluent, this represents a potentially severe disease exposure risk to labourers working on the land and also to consumers of the produce. Some of the crops grown would represent a high risk to consumers, such as salads and other crops that may be eaten raw. It was beyond the scope of the Study to investigate these issues (although there is an urgent need to do so), but advantage was taken of the soil samples taken during the site surveys for examination of residual pathogens and parasites since these would provide a useful comparison with soil samples taken from selected field trials carried out by the Study. The sampled areas for soil and plants are presented in table1.

Table1: Areas selected for sampling, date of first planting and current cropping in the three main area of Gabal El Asfar Old Farm

\begin{tabular}{lllll}
\hline $\begin{array}{l}\text { Plantation } \\
\text { Ref. No. }\end{array}$ & $\begin{array}{l}\text { Date } \\
\text { planting }\end{array}$ & $\begin{array}{l}\text { Duration } \\
\text { of } \\
\text { irrigation }\end{array}$ & $\begin{array}{l}\text { Current } \\
\text { planting }\end{array}$ & $\begin{array}{l}\text { Intercropping } \\
\text { at } \\
\text { sampling }\end{array}$ \\
\hline Southern area & & & \\
53 & 1928 & 69 & Seedless orange & \\
52 & 1954 & 69 & Seedless orange & Maize \\
13 & 1928 & 67 & Valencia orange & \\
75 & 1933 & 64 & Mandarin & \\
76 & 1933 & 64 & Mandarin & \\
67 & 1954 & 43 & Orange & Maize \\
65 & 1958 & 39 & Orange & Maize \\
22 & 1960 & 37 & Valencia Orange & Maize \\
23 & 1960 & 37 & Orange & Maize \\
12 & 1962 & 35 & Lemon & \\
61 & 1965 & 32 & Orange & \\
62 & 1965 & 32 & Orange & \\
20 & 1972 & 25 & Orange & \\
21 & 1972 & 25 & Valencia Orange & \\
40 & 1984 & 13 & Lemon & \\
73 & 1989 & 8 & Mandarin & \\
\hline
\end{tabular}

Table 1: Areas selected for sampling, date of first planting and current cropping in the three main area of Gabal El Asfar Old Farm - continued

\begin{tabular}{lllll}
\hline $\begin{array}{l}\text { Plantation } \\
\text { Ref. No. }\end{array}$ & $\begin{array}{l}\text { Date } \\
\text { planting }\end{array}$ & $\begin{array}{l}\text { of Duration of Current planting } \\
\text { sewage } \\
\text { irrigation }\end{array}$ & $\begin{array}{l}\text { Intercropping } \\
\text { at time of } \\
\text { sampling }\end{array}$ \\
\hline Northern area & & & \\
2 & 1914 & 83 & Pecan & \\
6 & 1914 & 83 & Pecan + lemon & \\
Forest & 1956 & 42 & Orange (balady) \\
A & 1956 & 43 & Valencia orange & \\
B & 1956 & 43 & Valencia orange & \\
C & 1956 & 43 & Valencia orange & \\
D & 1956 & 43 & Sweet orange & \\
28 & 1962 & 35 & Soliman pasha Maize \\
& & & orange & \\
29 & 1962 & 35 & Pecan & \\
2 & 1986 & 11 & Mandarin & \\
5 & 1987 & 10 & Seedless orange & \\
7 & 1987 & 10 & Valencia orange & \\
10 & 1991 & 6 & Khalili orange & \\
14 & 1992 & 4 & Valencia orange & \\
2 & 1993 & 4 & Mandarin &
\end{tabular}

\begin{tabular}{llll}
93 & 1914 & 83 & Seedless orange \\
56 & 1961 & 36 & Mandarin \\
82 & 1967 & 30 & Valencia orange \\
2 & 1977 & 20 & Mandarin \\
5 & 1981 & 16 & Mandarin \\
12 & 1988 & 9 & Lemon \\
8 & 1988 & 8 & Seedless orange \\
11 & 1989 & 7 & Mandarin \\
1 & 1992 & 5 & Valencia orange \\
\hline
\end{tabular}

Chemical analyses for soil $(0-30 \mathrm{~cm})$ depth and plant samples were carried out according to the methods described by [6] and [7] and total potential toxic elements [7]. The data were statistically analyzed using software package (Cohort2).

\section{RESULTS AND DISCUSSION}

The heavy metal contents of citrus leaves and fruit (orange - eleven sampling sites; mandarin - four sampling sites), and total and DTPA extractable concentrations in soils were measured in samples collected from different areas of the Farm during two site surveys .

Total and DTPA concentrations of heavy metals in the surveyed soils showed significant enrichment by long-term irrigation with sewage effluent. For example, the maximum total concentrations of $\mathrm{Zn}$ and $\mathrm{Cu}$ were 530 and $366 \mathrm{mg} \mathrm{kg}^{-1}$, respectively, representing a potential risk to crop yields (Tables 2 and 3 ). The maximum Cd concentration detected was $9 \mathrm{mg} \mathrm{kg}^{-1}$ and may be a potential risk to the human food chain from uptake into staple crops grown at the farm.

Table 1: Statistical summaries of total and extractable trace elements in soil and concentrations in citrus fruit from Gabal El Asfar Old Farm (Survey 1)

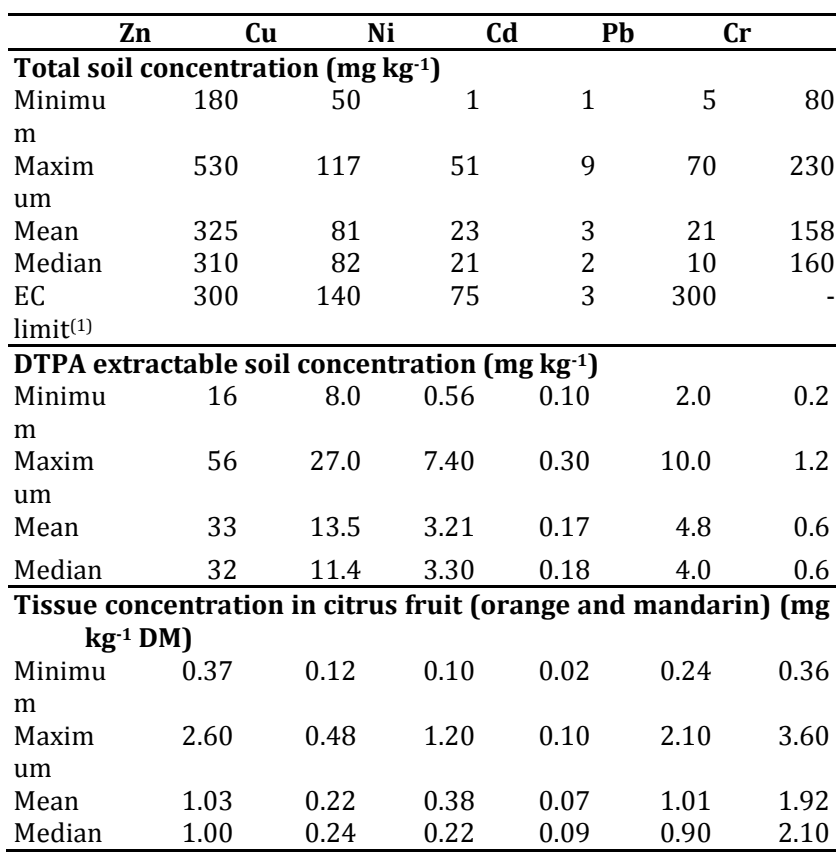

Note: (1) European maximum soil limit value (CEC Directive 86/278/EEC)

$\mathrm{n}=15$

DTPA extractable metals were significantly $(\mathrm{P}<0.001)$ correlated with the total contents of $\mathrm{Zn}\left(\mathrm{r}=0.91^{* * *}\right), \mathrm{Cu}\left(\mathrm{r}=0.83^{* * *}\right), \mathrm{Ni}$ $\left(\mathrm{r}=0.63^{* * *}\right)$ and $\mathrm{Pb}\left(\mathrm{r}=0.85^{* * *}\right)$ in soil when data from both surveys were pooled for statistical evaluation (Table 4 and Figure 1). There was also evidence of a weak relationship between DTPA extractable $\mathrm{Cd}$ and the total soil concentration, although this only just achieved significance at $\mathrm{P}=0.05$. However, when bioavailability was assessed on the basis of data from the chemical analysis of citrus fruits and leaves, there were no significant relationships apparent between the concentrations of heavy metals in plant tissues and the corresponding amounts of total or DTPA extractable metals in soil 
(Table 5; Figures 2 - 4). Leaf $\mathrm{Zn}$ and $\mathrm{Cu}$ concentrations were in the low (16-24 and 3.6-4.9 $\mathrm{mg} \mathrm{kg}^{-1}$, respectively) to optimum (25-100 and $5-16 \mathrm{mg} \mathrm{kg}^{-1}$, respectively) ranges for citrus and the other heavy metals were within normal ranges. Chemical analysis of citrus leaves indicated that $\mathrm{Cu}$ status was potentially within the deficient range in some cases, despite high soil concentrations observed for this element. Furthermore, there was no significant relationship detected between soil and leaf $\mathrm{Cu}$ demonstrating the minimal risk of phytotoxicity from this element in sludge-treated soil.

Table 3: Statistical summaries of total and extractable heavy metals in soil and concentrations in citrus leaves from Gabal El Asfar Old Farm (Survey 2)

\begin{tabular}{|c|c|c|c|c|c|c|}
\hline Zn & \multirow{2}{*}{ cuncentrat } & $\mathrm{Ni}$ & Cd & \multirow[t]{2}{*}{$\mathbf{P b}$} & \multicolumn{2}{|c|}{$\mathbf{C r}$} \\
\hline \multicolumn{5}{|c|}{ Total soil concentration (mg kg-1) } & & \\
\hline $\begin{array}{l}\text { Minimu } \\
\mathrm{m}\end{array}$ & 32 & 7 & 9.8 & 0.2 & 16 & 2.4 \\
\hline $\begin{array}{l}\text { Maxim } \\
\text { um }\end{array}$ & 143 & 366 & 92 & 4.6 & 290 & 376 \\
\hline Mean & 95 & 67 & 45 & 1.6 & 70 & 89 \\
\hline Median & 103 & 54 & 38 & 1.4 & 60 & 82 \\
\hline \multicolumn{7}{|c|}{ DTPA extractable soil concentration (mg kg-1) } \\
\hline $\begin{array}{l}\text { Minimu } \\
\mathrm{m}\end{array}$ & 4.0 & 2.2 & 9.8 & 0.02 & \multicolumn{2}{|c|}{$1.4<\mathrm{LoD}$} \\
\hline $\begin{array}{l}\text { Maxim } \\
\text { um }\end{array}$ & 18.8 & 42.5 & 92 & 0.88 & 21 & 0.3 \\
\hline Mean & 15.2 & 15.8 & 45 & 0.21 & 8.7 & 0.1 \\
\hline Median & 16.6 & 13.6 & 38 & 0.14 & 7.0 & 0.1 \\
\hline \multicolumn{7}{|c|}{ Tissue concentration in citrus leaves $\left(\mathrm{mg} \mathrm{kg}^{-1} \mathrm{DM}\right)$} \\
\hline $\begin{array}{l}\text { Minimu } \\
\mathrm{m}\end{array}$ & 1.2 & 1.0 & $0.8<\mathrm{LoD}$ & & 0.5 & 0.2 \\
\hline $\begin{array}{l}\text { Maxim } \\
\text { um }\end{array}$ & $150^{(1)}$ & 9.4 & 10.0 & 0.2 & 30.0 & 4.1 \\
\hline Mean & 24.8 & 3.8 & 4.3 & 0.1 & 12.4 & 2.0 \\
\hline Median & 20.9 & 3.5 & 4.0 & 0.1 & 11.4 & 2.1 \\
\hline
\end{tabular}

Note: $n=41$

Table 4: Linear regression models $(y=a+b x)$ of the relationships between the DTPA extractable and total concentrations of heavy metals in soil for pooled data from Survey 1 and 2

\begin{tabular}{lrrrr}
\hline $\begin{array}{l}\text { Eleme } \\
\text { nt }\end{array}$ & $\begin{array}{l}\text { Intercept } \\
\text { (a) }\end{array}$ & Slope (b) & $\begin{array}{l}\text { Correlation } \\
\text { coefficient } \\
\text { (r) }\end{array}$ & Significance (P) \\
\hline $\mathrm{Zn}$ & 7.4 & 0.08 & 0.91 & $<0.001^{* * *}$ \\
$\mathrm{Cu}$ & 6.0 & 0.13 & 0.83 & $<0.001^{* * *}$ \\
$\mathrm{Ni}$ & 1.3 & 0.05 & 0.64 & $<0.001^{* * *}$ \\
$\mathrm{Cd}$ & 0.14 & 0.03 & 0.29 & $0.03^{*}$ \\
$\mathrm{~Pb}$ & 2.8 & 0.08 & 0.85 & $<0.001^{* * *}$ \\
$\mathrm{Cr}$ & 0.09 & 0.001 & 0.38 & $0.004^{* *}$ \\
\hline
\end{tabular}

Table 2: Correlation coefficients (r) of relationships between heavy metal concentrations in soil and citrus at Gabal El Asfar old Farm

\begin{tabular}{lrrrr}
\hline $\begin{array}{l}\text { Eleme } \\
\text { nt }\end{array}$ & \multicolumn{1}{c}{ Fruit (n= 15) } & \multicolumn{2}{c}{ Leaves (n= 41) } \\
& Total & \multicolumn{1}{c}{ DTPA } & Total & \multicolumn{1}{c}{ DTPA } \\
\hline $\mathrm{Zn}{ }^{(1)}$ & $-0.11 \mathrm{~ns}$ & $-0.03 \mathrm{~ns}$ & $-0.12 \mathrm{~ns}$ & $-0.05 \mathrm{~ns}$ \\
$\mathrm{Cu}$ & $0.27 \mathrm{~ns}$ & $-0.03 \mathrm{~ns}$ & $0.36 \mathrm{~ns}$ & $0.24 \mathrm{~ns}$ \\
$\mathrm{Ni}$ & $0.06 \mathrm{~ns}$ & $-0.35 \mathrm{~ns}$ & $0.38 \mathrm{~ns}$ & $0.18 \mathrm{~ns}$ \\
$\mathrm{Cd}$ & $0.39 \mathrm{~ns}$ & $0.35 \mathrm{~ns}$ & $0.35 \mathrm{~ns}$ & $0.47 \mathrm{~ns}$ \\
$\mathrm{~Pb}$ & $0.24 \mathrm{~ns}$ & $-0.24 \mathrm{~ns}$ & $-0.10 \mathrm{~ns}$ & $0.04 \mathrm{~ns}$ \\
$\mathrm{Cr}$ & $0.09 \mathrm{~ns}$ & $0.01 \mathrm{~ns}$ & $0.01 \mathrm{~ns}$ & $-0.05 \mathrm{~ns}$ \\
\hline
\end{tabular}

Note: ns, not significant at $\mathrm{P}=0.05$

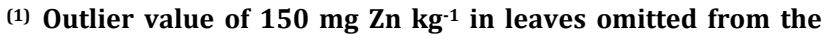
correlation analysis on leaf tissue content
These data confirm international experience with the sludge use in agriculture, which demonstrates that both $\mathrm{Cu}$ and $\mathrm{Ni}$ are unlikely to be phytotoxic when normal sludges produced at WWTPs are applied to farmland at agronomic rates in practice. $[8,9]$ This is because $\mathrm{Cu}$ is relatively tightly bound to soil organic matter limiting its mobility in sludge-treated soil and plants are also able to control the accumulation of $\mathrm{Cu}$ in their tissues much more so than for $\mathrm{Zn}$ or $\mathrm{Ni}$. Nickel poses little actual risk to crops in practice because concentrations in sludge are small relative to its phytotoxic threshold content in sludge-amended soil. The results presented here were consistent with earlier surveys of citrus at the Old Farm, which were optimistic about the positive, nutritional benefits of sewage irrigation for crop production.

Zinc is the element associated principally with the risk of phytotoxicity in sludge-treated agricultural land. The $\mathrm{Zn}$ concentrations detected in soil sampled in the second survey of Gabal El Asfar Old Farm were modest and below the considered phytotoxic concentration. Nevertheless, the Zn content of soil was raised by almost $300 \%$ above background, but there was no evidence of increasing $\mathrm{Zn}$ concentrations in citrus leaves (Table 5; Figures 2 and 3). These data indicate that $\mathrm{Zn}$ phytotoxicity is very unlikely from recycling sewage sludge to citrus crops.

Cadmium is the only element of concern in terms of the risk to human health from uptake into food crops grown on sludge-treated soil. The total Cd concentration in soil at Gabal El Asfar Old Farm was raised to a value 3 times the maximum EU limit for this element in sludge-treated agricultural soil. Despite the marked increase in soil Cd content, there was no detectable transfer into citrus leaves or fruit (Figure 4). The absence of Cd uptake into citrus fruit is to be expected because fruits are amongst the least sensitive plant parts to $\mathrm{Cd}$ accumulation. These data emphasise the minimal risk to the human diet from $\mathrm{Cd}$ in fruit crops grown on sludge-treated soil.

Leaf tissues of a number of inter-crops at Gabal El Asfar were also sampled in the survey including maize $(n=9)$ and one sample each of egg plant, pepper and potato. In all cases, leaf tissue concentrations were low and in some cases $\mathrm{Cu}$ status was below the deficiency threshold. The $\mathrm{Cd}$ content in leaves was small and generally $<0.02 \mathrm{mg} \mathrm{kg}^{-1} \mathrm{DM}$.

Lead was readily extracted from soil by the DTPA reagent (Figure 1), but is strongly bound to the soil matrix and is not transferred to crop tissues. The chemical analysis of citrus leaves and fruit confirmed the $\mathrm{Pb}$ accumulation in plant parts to be negligible (Table 4). Uptake of $\mathrm{Cr}$ into plant tissues is also restricted because of the capacity of soil to bind this element strongly in unavailable forms. In this case, however, the DTPA extractable fraction of this element was small and reflected the low bioactivity of $\mathrm{Cr}$ in sludge-treated soil (Figure 1 and Table 4).

DTPA is widely used in nutrient diagnosis as a tool for assessing potential soil deficiencies. However, these results show that the degree of extractability of a particular element does not necessarily provide a measure of its bioavailability to crops for assessing toxicological risks of heavy metals to crops or human health in sludge-treated desert soil. Soil extraction with DTPA was not a reliable indicator of bioavailability to citrus in reclaimed desert soil. Soil chemical extraction techniques should be interpreted with extreme caution when considering the environmental implications of recycling sewage sludge on agricultural land under Egyptian conditions.

Similar results were reported by [1] who indicted that after 85 years sewage farming at El-Gabal Al-Asfer, PTEs like Fe, $\mathrm{Zn}, \mathrm{Mn}, \mathrm{Cu}$, and $\mathrm{Pb}$ accumulated in the upper soil. $[2,3]$ found that the longer the period of irrigation with sewage effluent the higher the level of PTEs accumulation in soil and concluded that the progressive increase of PTEs in the soil represents serious risk to the cultivated plants. [4] found that soil irrigated for 75 years with sewage effluent showed increment in the total content of PTEs compared to control. The obtained values were 316.9, 276.4, 9.31, 43.81 and $213.3 \mathrm{ug} / \mathrm{g}$ soil for $\mathrm{Zn}, \mathrm{Cu}, \mathrm{Cd}, \mathrm{Ni}$, and $\mathrm{Pb}$. respectively. They added that all values 
were remarkably over the safe values of these PTEs that should be found in soils. In Germany [5] in a study aimed to determine whether $>110$ years of sewage application has led to recognizable changes in the metal chemistry of soils from former sewage farms came to similar conclusion.
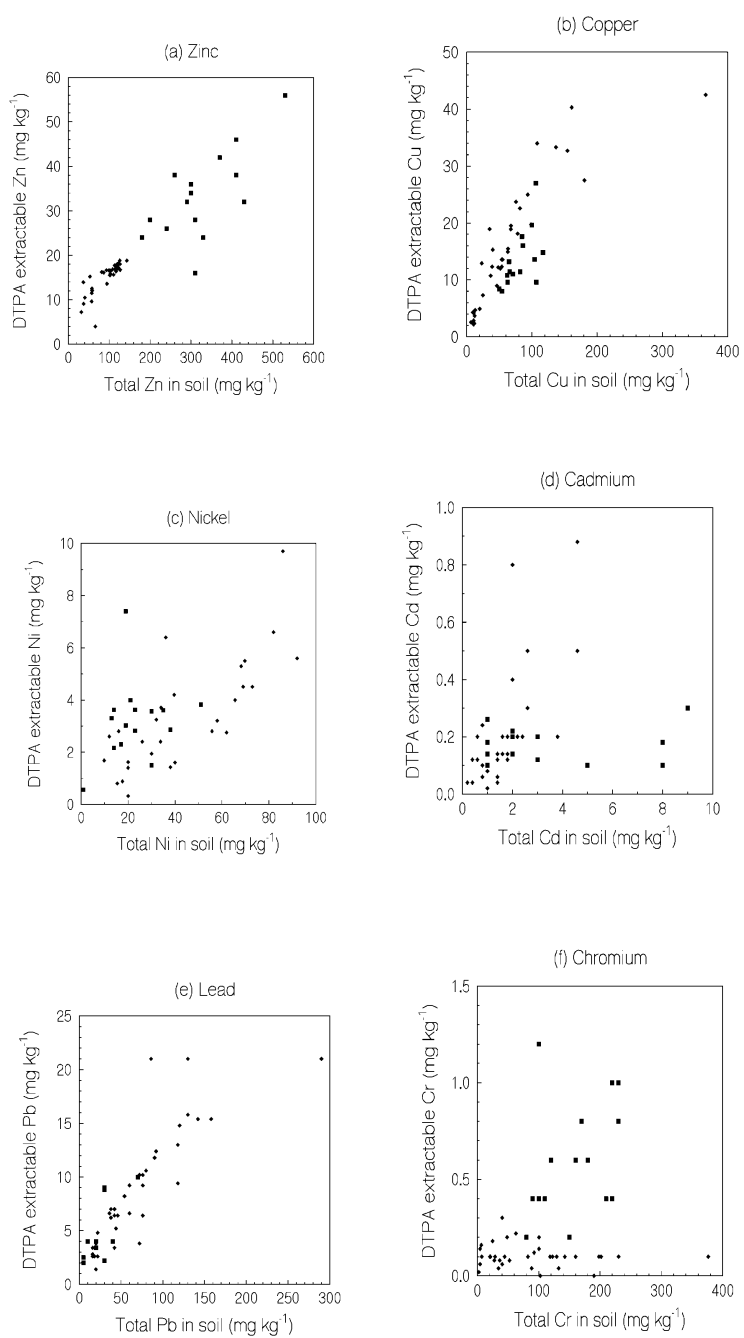

Fig. 1: DTPA extractable concentrations of heavy metals in relation to the total heavy metal content in soil from Gabal El Asfar Old Farm

( $\square$, Survey 1; $\diamond$, Survey 2).
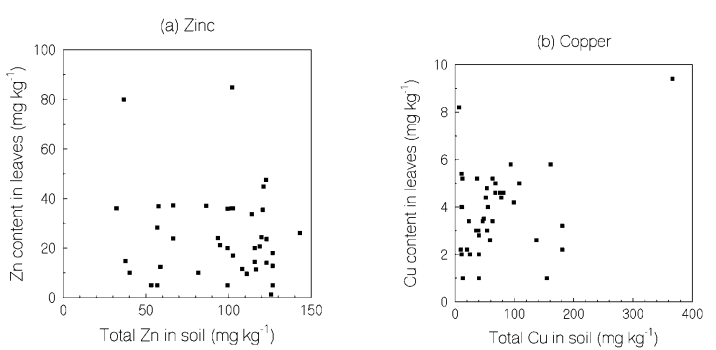

Fig.2: Concentrations of (a) $\mathrm{Zn}$ and (b) $\mathrm{Cu}$ in leaves of citrus in relation to the total content in soil from Gabal El Asfar Old Farm (Survey 2) (a) Zinc

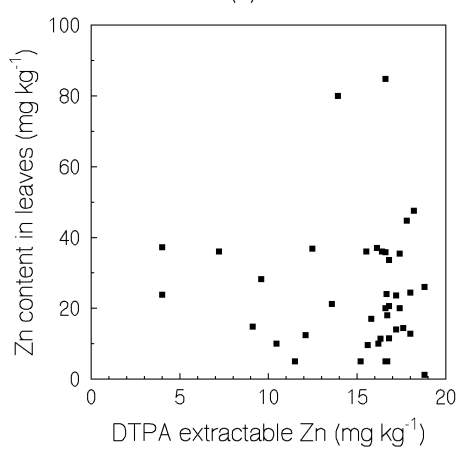

(b) Copper

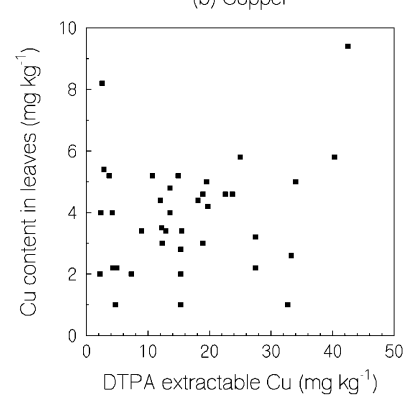

Fig.3: Concentrations of (a) $\mathrm{Zn}$ and (b) $\mathrm{Cu}$ in leaves of citrus in relation to the DTPA extractable contents in soil from Gabal El Asfar Old Farm (Survey 2).

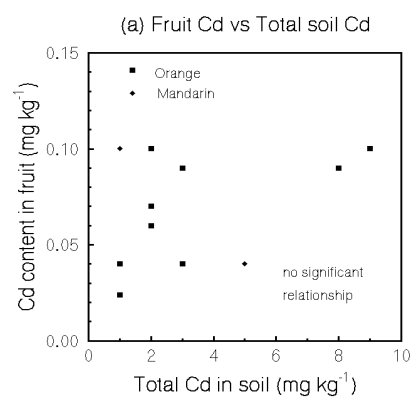

(b) Fruit Cd vs Extractable Cd

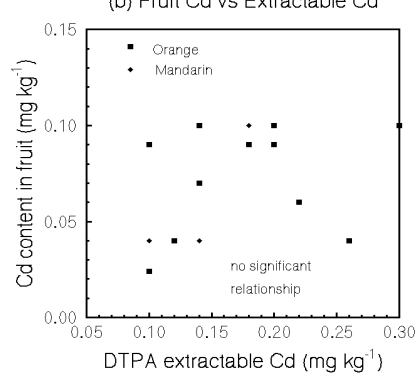

Fig. 4: Cadmium concentrations in citrus fruit in relation to (a) total and (b) DTPA extractable Cd content in soil at Gabal El Asfar Old Farm (Survey 1). 


\section{CONCLUSION}

The study of long-term contamination of soil with heavy metals has not demonstrated a potential risk to crop quality and yield or human health from the slow accumulation of heavy metals in sludge-treated agricultural soil. Heavy metal concentrations in plant tissues remained low and within normal ranges despite significant increases in soil content after long-term irrigation with sewage effluent. Concentrations of heavy metals in plant tissues were not related to total or DTPA extractable metals in contaminated soil. DTPA may not be a sufficiently reliable indicator of actual phytoavailability of trace elements in sludge-treated soil, although it is accepted that DTPA is widely used in nutrient diagnosis assessment.

This study of long-term contamination of reclaimed desert soil has demonstrated, and provides assurance of, the minimal risk to crop quality, yield and human health from heavy metals applied to soil in sewage sludge for desert reclamation and fruit production. A more detailed analysis of dietary exposure to $\mathrm{Cd}$ under Egyptian conditions is recommended, following the approaches adopted in the UK and US for setting Cd soil limits or loading rates for this element. Such information would be valuable in formulating the long-term management strategy of the site and for sludge and effluent reuse generally in Egypt.

\section{REFERENCES}

1. Abdel-Sabour M, et al., 1994. On the optimum use of municipal waste water and organic wastes for ameliorating sandy soils. NARP project no. AID US. Vols. 263-0152. Nuclear Research Center.

2. Abdel-Shafy H, Sayed S, Yhaya-Omar T. Risk assessment of sewage reuse on the sandy soil of the Abu-Rawash desert, Egypt. Environ Prot Eng. 2003;29:5-21.
3. Abo-el-Abbas Y. Behavior of trace elements in ecosystem of the urbanized area at NE Cairo/Egypt .GSA Annual Meeting, November 5-8. MA: Boston; 2001. p. 175.

4. Chapman HD, Oratt FE. Methods of analysis of soil. USA: Plant and Water, University of CaIifomia; 1961.

5. Cottenie A, Verlea M, Krekens L, Velghe G, Bcamerlynck R. Chemical Analysis of Plant and Jackson, M.L., (1967). Soil Chemical Analysis. Prentic Han of India. New Delhi; 1982. p. 251-80.

6. Kamel M, Husein E. Effect of long-term irrigation with sewage effluents on some PTE content in soils and plants in El-Gabal Al-Asfer farm. Egypt. J Agric Sci. 2007;32:6261-70.

7. Lottermoser BG. Effect of long-term irrigation with sewage effluent on the metal content of soils, Berlin, Germany. Environ Geochem Health. 2012;34(1):67-76. doi: 10.1007/s10653-011-9391-5, PMID 21547584.

8. Rattan RK, Datta SP, Chhonkar PK, Suribabu K, Singh AK. Longterm impact of irrigation with sewage effluents on heavy metal content in soils, crops and groundwater-a case study. Agric Ecosyst Environ. 2005;109(3-4):310-22. doi: 10.1016/j.agee.2005.02.025.

9. Smith SR, Abd El Lateef EM, Hall JE, Rasheed AA 1995. The agricultural use of sewage sludge in warm climates, with special reference to Egypt. WRc Medmenham, UK.

10. Smith SR, Abd El Lateef EM, Hall JE, Rasheed AA 1999. Scientific justification for agricultural use of sewage sludge in Egypt. WRc Medmenham, UK.

11. Soils Lab. Anal. Agroch. Fac Agric. Gent, Belgium: State University 